\title{
An approach to a methodology for the analysis and characterization of disused railway lines as a complex system
}

\author{
A. Eizaguirre-Iribar, L. Etxepare Igiñiz \\ \& R. J. Hernández-Minguillón \\ Department of Architecture, University of the Basque Country \\ UPV/EHU, Spain
}

\begin{abstract}
Since the second half of the 20th century and especially in territories where the train had been dependent on industrial development, there are many kilometres of disused railway lines setting a railway heritage of great interest. Nevertheless, the passage of time and the lack of use have led to many heritage elements being in danger of disappearing, if not having already disappeared. Furthermore, most of the actions for their protection, restoration or putting in value carried out until today, have focused on component item/element, instead of understanding the line as a territorial system, formed not only by the nodes but also by the connecting threads.

This paper aims to analyze and characterize the disused railway heritage as a complex system, focusing on the methodology and tools. The way to address the issue attempts to avoid the decomposition of the system and favour the maintenance of the structuring nature that railway lines originally had in each territory, which is precisely one of the most important features to put them in value in the new territorial view of the 21th century. The paper develops the application of this methodology on a case study in southwest Europe: disused railway lines in the Basque-Navarre territory.

Keywords: disused railway line, railway heritage, system, territorial structuring, methodology, GIS, nodes, the Basque Country, Navarre.
\end{abstract}




\section{Introduction}

The arrival of the railroad, in the 19th century, was linked to industrialization and subsequent urban development, so the railway took an active part in the profound changes that were being produced in the city [1]. However, the competition from road transport or the industry decline induced the closure of many of these railway lines throughout the second half of the 20th century. Nowadays, the disused railway lines set a railway heritage of great interest, but the lack of use and passage of time have led to them being in danger of disappearing.

Nevertheless, the current broad concept of heritage and its territorial character make possible the proposition of these lines as territorial structuring systems, favoring the development of their environment.

The concept of heritage has been extended from monument to cultural and natural heritage in last decades [2], which has led to the emergence of new categories with broader nature (ensemble, site, landscape, route, etc). Although the promotion of the railway heritage is still at an early stage, this heritage has been already recognized as cultural heritage and it is linked to other subtypes of heritage, such as industrial or public works. This has helped to understand the railway heritage in its entirety. In addition, industrial railway heritage assets are classified into different groups as movable assets, real state, facilities or infrastructure of the road [3]. Thus, a system in which the value comes from the existence of a structured set with a global significance is formed [4] and the principal value of its set of components is being an integral part of a whole [5].

Furthermore, railway heritage is directly related to the surrounding territory and landscape. The railroad was closely linked to the territory in its arrival by structuring and organising it hierarchically. Thus, it had a selective power to choose some areas and exclude others [1]. Moreover, disused railway lines are also in constant interaction with their environment. That is why, nowadays they are part of the concept of cultural landscape defined by UNESCO in 2008 [6] or cultural route defined by ICOMOS in 2008 [7]. However, territory and landscape are understood as a reality in constant evolution [8]. Hence, the closure of railway lines should be understood as another turning point in the territorial evolution and as an excellent starting point for the next stage.

The broad concept of heritage and its territorial character are clear steps for a comprehensive vision, and should also involve an integrated and crosscutting management. Nevertheless, a mismatch between theoretical and practical achievements demonstrates the difficulty to apply this integrated view [4]. Indeed, the actions taken for their protection, restoration and enhancement, are fulfilled in some of isolated elements losing the system nature they once had.

On the one hand, there have been initiatives to protect these systems with a comprehensive vision. Some examples are the protection as "industrial landscape" proposed in the Basque Country (Inventory of Industrial Landscapes of the Autonomous Community of the Basque Country) [9] or the existence of the legal figure of protection of "industrial landscape" in Navarre [10], both in Spain. But in practice, the legally protected items are isolated elements and their protection figures have a limited scale. 
On the other hand, restoration and enhancement interventions are generally focused on isolated elements and buildings (nodes) or on the line, but not on the whole. Interventions in nodes mainly focus on the rehabilitation of stations and their environments, and they may be carried out by the councils of each municipality or specialized associations, such as the Railway Heritage Trust in UK or the Rail Heritage Trust of New Zealand. In spite of the work of documentation, protection and restoration that they have developed, each element is considered in isolation and with varied uses, which may lead to the fragmentation of the system. Interventions in line or path have specially focused on their reuse as non motorised transport infrastructures. The so-called Greenways or Rail-Trails are thus created, which are widespread throughout Europe, but also in the US and Canada. The restoration of the built railway heritage is proposed as part of them, although in practice this type of intervention focuses on a single system node. It should finally be noted that the first theoretical guidelines were developed for putting in value stations and other built railway heritage as a whole [11].

All this considered, this paper emphasizes the fact that the analysis of the disused railway lines should have a comprehensive vision in order to achieve the same view in their protection or future interventions. This paper aims to create a comprehensive analysis method for the characterization and classification of disused railway lines of a territory, understanding them as complex systems. This conception enables keeping the structuring nature they once had in the territory. This is one of the most important features for their possible reuse and influence in the development of their environment. In the same way, the knowledge of their structuring capability is helpful in the creation of future strategies.

\section{The concept of disused railway system}

A system is a complex set of interacting elements. Taking into consideration the theory of Systems, a system cannot be defined or characterized from its elements in isolation, but from the parts and the interactions between them, hence the phrase "the whole is more than the sum of its parts" [12]. It is necessary to know and comprehend the elements which were involved to achieve the interconnection, in order to understand the whole system [13], since each element becomes meaningless outside the set to which it belongs. As Montaner said [14], a system is "a set of heterogeneous elements (material or otherwise) of different scales, which are interrelated. They have an internal structure that adapts strategically to the complexity of the context and constitutes a whole, which is not explained by the mere sum of its parts. Each part of the system is based on another; there are no isolated elements".

A railway is a territorial system, formed not only by the nodes but also by the connecting thread (fig. 1). The connecting thread is the path, which creates longitudinal flows in the territory, while the nodes are the areas of stations or halts that create the connection between the rail line and the territory. The line consists of a linear infrastructure and all specific elements that make it possible, 


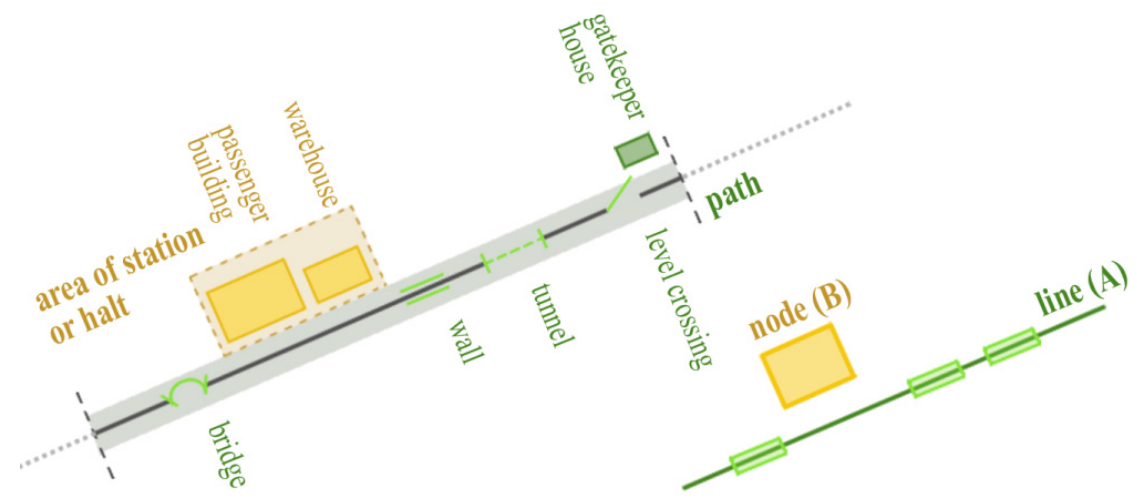

Figure 1: Diagram of the railway system and its components.

such as bridges, tunnels, level crossings or gatekeeper houses. Meanwhile the node can be formed either by a simple shelter or by a set of buildings (passenger building, warehouse, garage, offices, houses, toilets, etc.).

The railway is a complex system which acted as a structuring element of the territory when it arrived. It had a favourable influence area around, which was served by the train, excluding territories through which the train did not pass and thereby creating a territorial hierarchy. The nodes in turn created a second hierarchy within the system. In this way, railways and their stations became into the axis of the city and society, into the hubs of the economic, social and cultural activities [15].

Disused railway lines are also understood as territorial systems composed of their nodes and connecting thread (fig. 2). Consequently, the set of built railway heritage acts as part of the system, where the line gives meaning to all elements, being its connection ability the most favourable feature to consider [11]. As
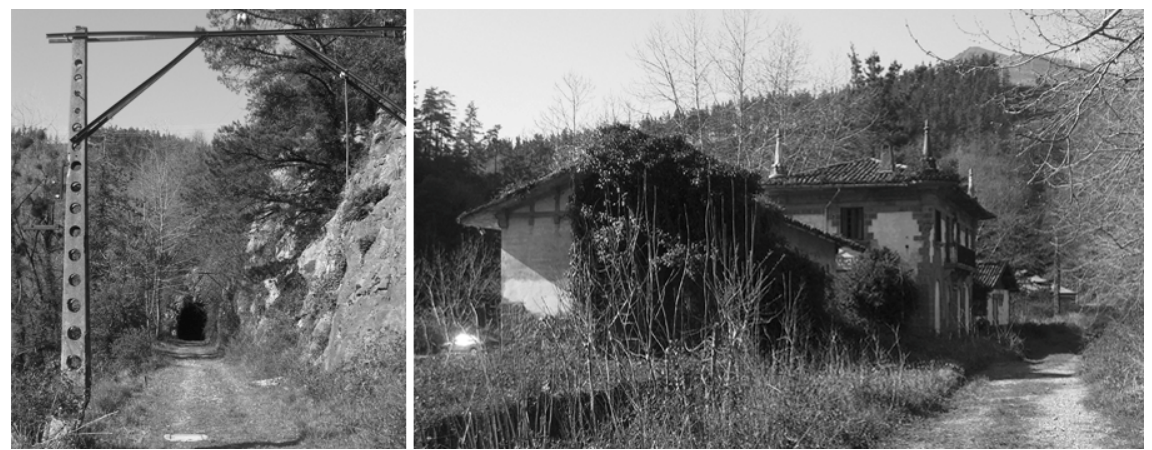

Figure 2: Components of a disused railway line; the line (left) and a node (right). 
Ferrari said, "a bridge is no longer an isolated monument but is part of the territorial system and that is where the linear infrastructure takes value" [5].

The considering of the railway heritage as a whole is a way to enable these enclaves to be integrated effectively into urban and territorial dynamics [16]. On the one hand, it ensures the conservation of endangered heritage and on the other hand, the structuring nature they once had, is restored. All of this should be attached to the socio-economic reality of the moment and future needs.

However, in disused railway lines specific changes could appear in relation to the scheme presented in fig. 1. Their nodes are formed by all railway buildings, including for example the gatekeeper houses, since they may accept a wide range of uses. Meanwhile, the connecting thread consists of the path and all construction elements that make it possible. Furthermore, in this case, the relation between the system and the territory is not only limited by the existing nodes, because any external element could work as a node due to the variety of possible future uses of the system.

\section{Comprehensive analysis method}

An approach to the methodology for the analysis and characterization of disused railway lines as a complex system is proposed in this article. Taking into consideration the previous definition given for the concept of system, the analysis covers both component elements and their relations. As result, the characterization of each selected disused railway line is obtained, with the aim of creating a classification of different systems refered to their capability to work as a structuring element in the territory. The higher the capability, the wider the range of future strategies that the line can include for a new use.

\subsection{Data collection and structure}

Historical data related to the period in which the railways were in use and their current status data is required for the proposed analysis. This collected data should be structured in three groups (line data, node data and territorial data) which will be managed by a Geographic Information System (GIS). In this way, each disused railway line (system) will be composed of a linear shapefile (path) and a point shapefile (nodes), whereas a polygon shapefile with municipal boundaries will be created to represent surrounding territorial data. The required attribute tables of these shapefiles are defined with the following characteristics:

- Line: ID; Name; Opening year; Route; Route distance; Gauge; Type of transport; Year of electrification; Year of closure; Current route; Current route distance; Current use;

- Nodes: ID; Name; Description; Buildings; Current buildings; Current use; Specific use; Current state; Area; Floors; x; y;

- Territory: ID; Name; Area; Population (beginning of the railway activity); Population (closure of the railway activity); Current population.

- Others: Other shapefiles will be used to represent towns and rural communities, rivers, protected natural areas or main infrastructures. 


\subsection{Data analysis}

The proposed comprehensive analysis will be performed in four areas: the line, the nodes, the relations between the system elements (internal) and the relations between the system and the surrounding territory (external).

Two variables are obtained in each analysis. One of them refers to the historical or constant state of the system, whereas the other refers to the current state. Depending on the combination of the range of these variables, the system will be classified on one of the five categories related to its territorial structuring capability.

1: Wide range capability (high ranges in the historical and current state).

4: Can have a wide range capability. (high range in one variable and middle in the other or high range in the historical state and low in the current)

2: Middle range capability (middle ranges in the historical and current state).

5: Can have a middle range capability (low range in one variable and middle in the other or low range in the historical state and high in the current).

3: Limited range capability (low ranges in the historical and current state).

It is considered that the historical analysis provides interesting data, especially in cases where the current analysis results are less favorable. A system with a high territorial structuration or integration in its historical status enables the recovery of this system with same characteristics.

\subsubsection{System elements or items}

On the one hand, the elements involved on the system will be analyzed, without taking into account the relations they have with other elements or its environment. In a railway system the main elements are two: the line and the nodes.

Related to the line (A in fig. 3), data such as track gauge or type of transport can be very characteristic to understand the evolution or the closure of a railroad. Nevertheless, the level of preservation of the line is considered as the main factor to define the system and its possible structuring effect on the territory. Therefore, the percentage of preserved line and the current state are measured. The last one consists of the state of preservation (ruin, poor, regular or good), its general use and the reversibility of the disappeared sections.

In reference to the nodes ( $\mathrm{B}$ in fig. 3), the collected data allows an easy measurement of the preservation level of built heritage, as well as the characterization of each system. The higher the level of preservation, the greater the possibilities for system recovery, assuming different types of uses. The percentage of preserved elements or items is the first variable, whereas their current state is the second. Three indicators are defined for the second variable: state of preservation (ruin, poor, regular or good), percentage of disused items and percentage of items with public use.

\subsubsection{Created relations}

On the other hand, the relations existing between the system elements and relations created between the system and the surrounding territory will be analyzed, thus defining two types of relations. 


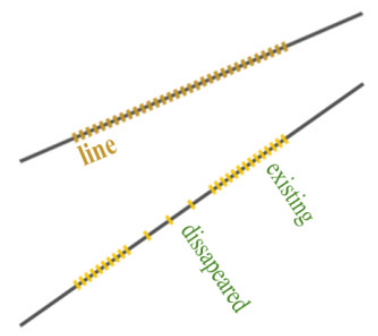

line (A)

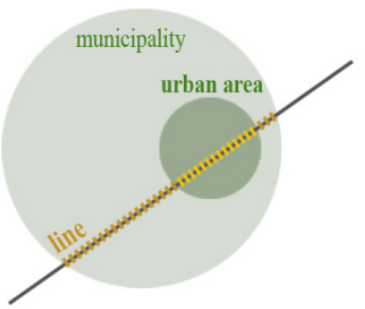

line/territory (D)

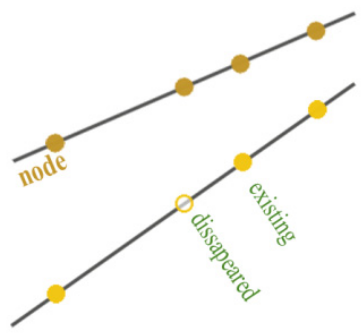

nodes (B)

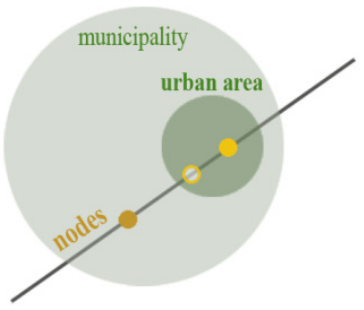

node/territory (E)

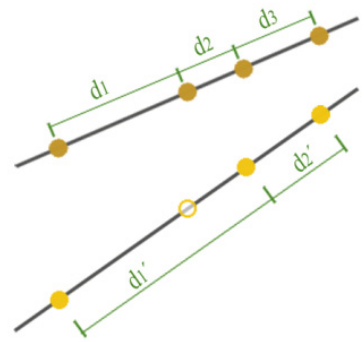

line/nodes (C)

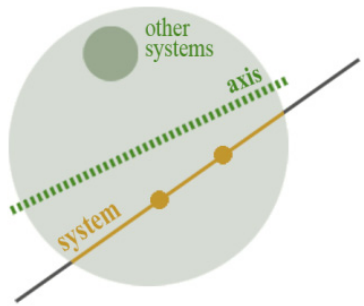

system/territory (F)

Figure 3: Components and created relations in the complex system.

The relations created between the system elements are called internal relations, in this case, those created between the line and the nodes ( $\mathrm{C}$ in fig. 3 ). The first variable, concerning the historical state of the line, is deduced from the distances between nodes, considering both all nodes and only those which comprised any building. The second variable is inferred by the distances between current existing nodes and the length of the line in relation to the floor area of the existing buildings.

The relations created between the system or its elements and the surrounding environment are called external relations. In this case, the line, the nodes and the whole system are related to the territory. First, in "line/territory" relations (D in fig. 3), the population and the municipal surface area concerning the line are analyzed for the historical state, while the population, the municipal surface area and the number of towns and rural communities related to the line are studied for the current state. In "node/territory" relations (E in fig. 3), the population and the municipal surface area regarding the number of nodes and buildings are analyzed for the historical state, while the population and the municipal surface area related to the number of nodes and their surfaces areas are studied for the current state. Finally, in "system/territory" relations ( $F$ in fig. 3), the existence of rivers or mountains crossing the line is observed for the historical or constant state. For the current state, two indicators are analyzed: 1) the existence of protected natural areas; 2) the existence of current or future elements for the strengthening of the line axis. 


\subsubsection{Uniformity of the system}

The conducted analysis focuses on the mean values for each data. A further examination, however, may allow a more accurate approximation. The construction of box-plot type graphs, from data of relations between nodes and line, allows deciding whereas a division of the analyzed systems into zones is necessary. One reason for the division could be that line sections with very different characteristics exist within the same system, due to an unequal distribution of the nodes or specific territorial characteristics. The interquartile range or the existence of outliers of such graphs will be considered for this.

\subsection{Results}

The results for each part of the analysis (A, B, C, D, E, F) will be represented in the previously defined categories $(1,4,2,5,3)$, by measuring the capability of territorial structuring of the system. These results should be represented in a two axes diagram, where the vertical axis represents the capability that each system has for working as a structuring element in the territory and the horizontal axis represents the uniformity of the analyzed factors. This allows comparing and classifying different systems in order to design future common strategies for their promotion.

\section{Case study: the Basque-Navarre territory}

The comprehensive analysis methodology has been applied in the main disused railway lines in the Basque Country and Navarre (Spain). The Basque Country is the territory with the highest percentage of kilometres of disused railway lines per $\mathrm{km}^{2}$ in the state [17]. The closure of the last line was in 1987 and, hence, the current deterioration of most of the assets begins to rise considerably. In the study twelve lines have been selected, which were used for the transport of goods and passengers. They are the ones that may have some potential in the regional planning of their surrounding areas.

A data collection and fieldwork have been performed to create the system shapefiles (fig. 4). Otherwise, the shapefiles concerning the territory were obtained from the spatial data infrastructures of each territory (Basque Country: geo.euskadi.net; Navarre: idena.navarra.es). Historical and current demographic data were also included from the Basque Statistics Institute (Eustat), the Statistical Institute of Navarre and the National Institute of Statistics, INE. In this study, the demographic data of 1930 and 1981 was compiled for regarding the historical state. In the first date, all selected lines had been already constructed, whereas in the second, all of them had been closed or were on the verge of it.

Currently, all selected lines have similar gauge (narrow gauge) or current use (greenway or cycle lane). That is why the paths remain at a high proportion although some kilometres have disappeared. Therefore, the part of the analysis refered to the line (A) has been neglected due to the similarities in the results.

The presented two variables (section 3.2) related to the nodes/items (B) have been obtained from collected data and divided into the four ranges, as table 1 


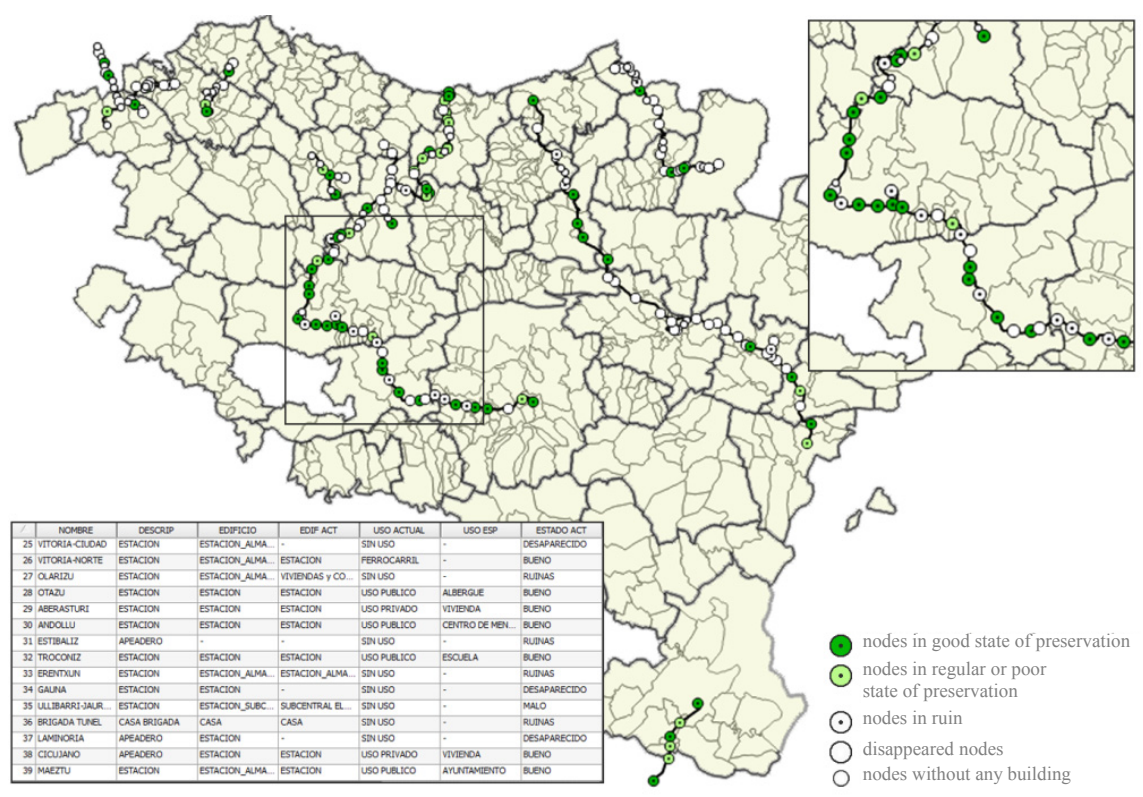

Figure 4: GIS concerning to disused railway lines of Basque-Navarre territory. This map shows the preservation state of the nodes.

shows. The first variable refers to the percentage of nodes preserved, whereas the second refers to the current state of preservation of them.

Depending on the combination of these variables, the disused railway lines are categorized in the previously presented five categories, which represent the capability range of territorial structuring of the system (B column in table 2).

The same categorization has been applied for the creating relations of the stydied railways. Results for each study area are also shown in table 2 .

The uniformity analysis of nodes/line relations, done by box-plot type graphs, shows that some railways lines need a division into zones for the achievement of more accurate results. For instance, in Urola railway two adjacent outliers are obtained, which represent the division of the system into two zones. In Irati and Bidasoa railways, some of its nodes have disappeared by zones, so some outliers far from the remaining values appear, creating different zones, two in Irati and three in Bidasoa. Finally in Vasco-Navarro railway, the obtained outliers are scattered and the division is not so clear, so a partition that fits the territorial distribution has been made (five zones). The results of the comprehensive analysis on the divided zones could be observed in the right part of table 2 .

Once that the comprehensive method has been carried out, the main conclusions of the analysis have been obtained. One the one hand, Urola railway has the best results because it was the last to close and it preserves almost all its nodes. This means that it has a high territorial structuring potential, in order to cover new uses beyond the current greenways. On the other hand, the results of Maltzaga-Zumarraga, Plazaola and Bilbao-Lezama railways shows they have 
fewer possibilities to assume different uses for the territorial structuring, leaving their future direction towards the use of their paths as territorial union.

Table 1: Node analysis which shows the preservation level of built heritage.

\begin{tabular}{|l||c||c||c|c|c|c|c|c||}
\hline \multirow{2}{*}{$\begin{array}{l}\text { Disused railway } \\
\text { lines }\end{array}$} & \multicolumn{1}{l||}{ items } & \multicolumn{1}{|c||}{ existing } & \multicolumn{3}{c||}{ state of preservation \% } & disused & public use \\
\cline { 2 - 9 } & $\mathrm{n}^{\mathrm{o}}$ & $\%$ & ruin & poor & regular & good & $\begin{array}{c}\% \text { of } \\
\text { existing }\end{array}$ & $\begin{array}{c}\% \text { of } \\
\text { in use }\end{array}$ \\
\hline Urola & 19 & 84.21 & 0.00 & 31.25 & 25.00 & 43.75 & 56.25 & 71.43 \\
\hline Maltzaga-Zumarraga & 6 & 16.67 & 100.00 & 0.00 & 0.00 & 0.00 & 100.00 & 0.00 \\
\hline Vasco-Navarro & 45 & 73.33 & 24.24 & 9.09 & 3.03 & 63.64 & 33.33 & 54.55 \\
\hline Durango-Elorrio & 3 & 66.67 & 0.00 & 0.00 & 0.00 & 100.00 & 0.00 & 100.00 \\
\hline Plazaola & 14 & 50.00 & 28.57 & 0.00 & 0.00 & 71.43 & 28.57 & 60.00 \\
\hline Tudela-Tarazona & 6 & 100.00 & 0.00 & 16.67 & 33.33 & 50.00 & 50.00 & 66.67 \\
\hline Traslaviña-Castro & 9 & 55.56 & 20.00 & 0.00 & 20.00 & 60.00 & 20.00 & 50.00 \\
\hline Sestao-Galdames & 10 & 20.00 & 0.00 & 0.00 & 50.00 & 50.00 & 0.00 & 100.00 \\
\hline Sondika-Mungia & 3 & 33.33 & 0.00 & 0.00 & 0.00 & 100.00 & 100.00 & 0.00 \\
\hline Bilbao-Lezama & 1 & 100.00 & 0.00 & 0.00 & 0.00 & 100.00 & 0.00 & 100.00 \\
\hline Irati & 19 & 31.58 & 16.67 & 0.00 & 33.33 & 50.00 & 16.67 & 0.00 \\
\hline Bidasoa & 21 & 23.81 & 20.00 & 0.00 & 0.00 & 80.00 & 20.00 & 0.00 \\
\hline
\end{tabular}

Table 2: $\quad$ Results for each area of the comprehensive analysis method.

\begin{tabular}{|c|c|c|c|c|c|c|c|c|c|c|c|}
\hline & $\mathrm{B}$ & $\mathrm{C}$ & $\mathrm{D}$ & $E$ & $\mathrm{~F}$ & & B & $\mathrm{C}$ & $\mathrm{D}$ & $\mathrm{E}$ & $\mathrm{F}$ \\
\hline Urola & 1 & 1 & 2 & 1 & 1 & U1 & 1 & 1 & 2 & 1 & 1 \\
\hline Maltzaga-Zumarraga & 3 & 3 & 2 & 3 & 2 & $\mathrm{U} 2$ & 4 & 1 & 1 & 2 & 1 \\
\hline Vasco-Navarro & 2 & 2 & 2 & 2 & 2 & VN1 & 4 & 2 & 2 & 3 & 1 \\
\hline Durango-Elorrio & 1 & 2 & 2 & 2 & 1 & VN2 & 2 & 3 & 2 & 2 & 3 \\
\hline Plazaola & 2 & 3 & 2 & 3 & 1 & VN3 & 1 & 2 & 2 & 3 & 2 \\
\hline Tudela-Tarazona & 1 & 4 & 2 & 5 & 5 & VN4 & 2 & 4 & 3 & 2 & 4 \\
\hline Traslaviña-Castro & 2 & 2 & 2 & 4 & 5 & VN5 & 1 & 4 & 3 & 1 & 4 \\
\hline Sestao-Galdames & 5 & 5 & 1 & 3 & 5 & I1 & 3 & 3 & 2 & 3 & 5 \\
\hline Sondika-Mungia & 2 & 5 & 2 & 5 & 2 & I2 & 2 & 2 & 3 & 2 & 4 \\
\hline Bilbao-Lezama & 1 & 2 & 2 & 3 & 3 & B1 & 3 & 4 & 1 & 2 & 1 \\
\hline Irati & 2 & 2 & 2 & 3 & 4 & B2 & 3 & 3 & 2 & 5 & 1 \\
\hline Bidasoa & 5 & 5 & 3 & 2 & 1 & B3 & 2 & 4 & 2 & 2 & 1 \\
\hline $\begin{array}{l}\text { 1: wi } \\
\text { capal }\end{array}$ & & & & & & & $\begin{array}{l}5: \\
\text { mid }\end{array}$ & $\begin{array}{l}\text { hav } \\
\text { rang }\end{array}$ & & $\begin{array}{r}3: \text { li } \\
\text { ran }\end{array}$ & \\
\hline
\end{tabular}

Fig. 5 shows the result of the analysis as a whole for each disused line related to the uniformity of these results. The systems situated in the right side of the graphic have the most uniform results. Thus, the same level of strategy could be applied for all analyzed areas. Otherwise, the systems situated in the left side show an imbalance in the necessities that each area has for future strategies. In this case, Vasco-Navarro and Urola railways present the most regular results while Bidasoa and Tudela-Tarazona railways present the most irregular ones. 


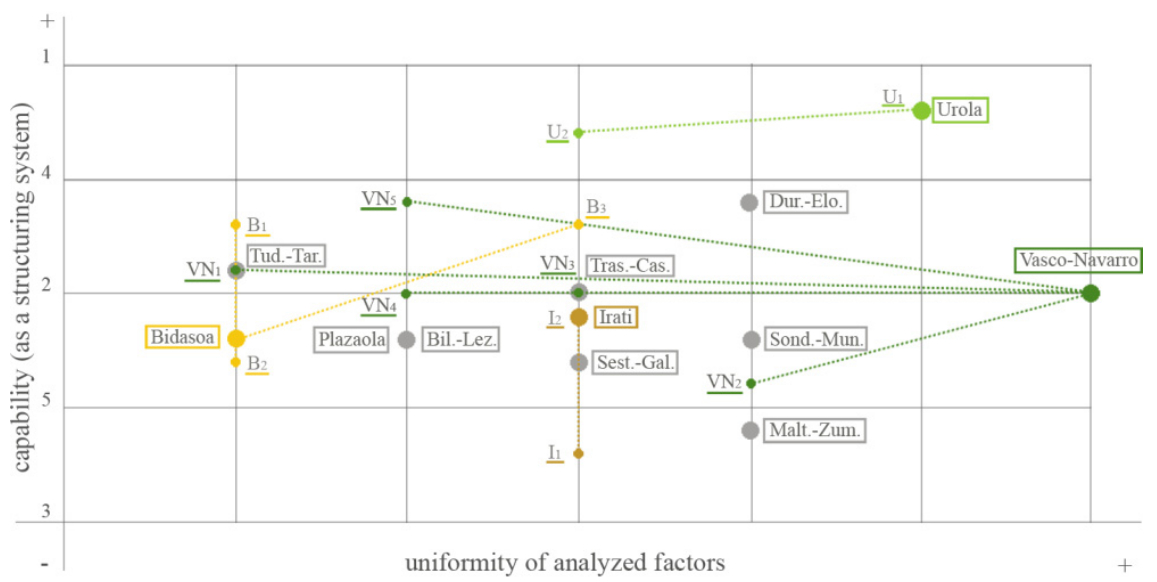

Figure 5: Comprehensive analysis results.

Related to the lines where a division into zones has been proposed, Irati and Bidasoa railways present a zone where the results are worse than the ones obtained before the division. It means that the division is adequate to understand the system in these two railways. However, in Urola railway case the division adds nothing new to the analysis. Finally, although there is a zone with different results, the proposed division in Vasco-Navarro railway is not clarifying, probably due to an excessive fragmentation.

\section{Conclusions}

This paper presents a novel methodology for the analysis of the disused railway lines as complex systems. It permits a more extensive study of them, where the surrounding territory is taken into consideration. In this way, the territorial structuring potential of the disused railway system is shown, in order to cover new uses beyond the current greenways while promoting the preservation of this heritage. The presented comprehensive analysis method may study the systems as a whole or could classify and compare them with each other.

On the one hand, the historical performance of the railway as a system and its integration into that period territory are considered in addition to the current data. They are essential for the creation of future strategies to take advantage of the structuring character they had in the past. On the other hand, the division of the study on the elements as themselves and on their relations is proposed. Due to the continuous damage and disappearance of these elements, a GIS software is employed in order to store, manage and update data easily.

The methodology has been applied to a real case, where the disused railways from the Basque Country (Spain) and Navarre (Spain) have been deeply studied. Furthermore, it should be commented that the presented method could be widespread to other territorial linear systems such as rivers and their hydroelectric plants or cattle routes. 


\section{Acknowledgement}

This research was supported by a research training grant from the Department of Education, Language policy and Culture of the Basque Government.

\section{References}

[1] Aguilar, I., La estación de ferrocarril puerta de la ciudad, Generalitat Valenciana: Valencia, 1988.

[2] Aguilar, I., La investigación sobre el Patrimonio Industrial. Una revisión bibliográfica. TST Transportes, Servicios y Telecomunicaciones, 1, pp. 169-186, 2001.

[3] García, A., Patrimonio Ferroviario Aragonés. Propuesta para una red de museos especializados. Jornadas Patrimonio Industrial y Obra Pública, eds. Gobierno de Aragón, Departamento de Educación, Cultura y Deporte Zaragoza, 2007.

[4] Porcal, M.C., El patrimonio rural como recurso turístico. La puesta en valor turístico de infraestructuras territoriales (rutas y caminos) en las áreas de montaña del País Vasco y de Navarra. Cuaderno de Turismo. Universidad de Murcia, 27, pp. 759-784, 2011.

[5] Ferrari, M., Paisaje y patrimonio en la línea ferroviaria 'Jujuy-La Quiaca'. Una propuesta de reutilización para el desarrollo local. Labor \& Engenho $L \& E, 6(1)$, pp. 89-108, 2012.

[6] UNESCO, Directrices Prácticas para la aplicación de la Convención del Patrimonio Mundial, Centro de Patrimonio Mundial de la UNESCO: Paris, 2008.

[7] ICOMOS, Carta de Itinerarios Culturales, 16 ${ }^{\mathrm{a}}$ Asamblea General del ICOMOS: Québec, 2008.

[8] Galindo, J. \& Sabaté, J., El valor estructurante del patrimonio en la transformación del territorio. Apuntes: Journal of Cultural Heritage Studies, 22(1), pp. 20-33, 2009.

[9] Gobierno Vasco, Inventario de Paisajes Industriales en el Ámbito de la Comunidad Autónoma del País Vasco, Departamento de Educación, Política Lingüística y Cultura, 2013.

[10] España, Ley Foral 14/2005, de 22 de noviembre, del Patrimonio Cultural de Navarra, B.O. de Navarra, 25 de noviembre de 2005.

[11] Llano-Castresana, U., Azkarate, A., \& Sánchez-Beitia, S., The value of railway heritage for community development. WIT Transactions on The Built Environment, 131, pp. 61-72, 2013.

[12] Von Bertalanffy, L., Teoría general de los sistemas: fundamentos, desarrollo, aplicaciones, Fondo de Cultura Económica: Madrid, 1993.

[13] Ferrari, M., Patrimonio ferroviario en el noroeste argentino. La línea Jujuy-La Quiaca, Universidad Pablo Olavide de Sevilla. Departamento de Geografía, Historia y Filosofía, 2010.

[14] Montaner, J.M., Sistemas arquitectónicos contemporáneos, Gustavo Gili: Barcelona, 2008. 
[15] González, M., Urrutikoetxea, J. \& Zárraga, K., Ferrocarril y capital humano. Dos eslabones fundamentales en el proceso vasco de modernización (1877-1930). VI Congreso de Historia Ferroviaria, Vitoria-Gasteiz, 2012.

[16] Tarchini, M.L., Infraestructura ferroviaria; reflexiones sobre el rol del patrimonio en las ciudades. X congreso Internacional CICOP 2010, Chile.

[17] FFE, Inventario de las líneas ferroviarias en desuso, Fundación de Ferrocarriles Españoles, 1993. 